\title{
Sosialisasi Dan Pembekalan Strategi Pemasaran Produk Olahan Pisang Pada Siswa Pondok
}

\author{
Dellia Mila Vernia $^{1}$, Sigit Widiyarto ${ }^{2}$, Dwi Narsih ${ }^{3}$, Mu'thia Mubasyira $^{4}$, \\ Leni Tiwinyanti ${ }^{5}$, \\ ${ }^{1}$ Prodi Pendidikan Matematika, FMIPA, Universitas Indraprasta PGRI Jakarta \\ Email : delliamilavernia@gmail.com \\ ${ }^{2,5}$ Prodi Pendidikan Ekonomi, FIPPS, Universitas Indraprasta PGRI Jakarta \\ Email : sigit.widiyanto372@gmail.com \\ 2,3 Prodi Pendidikan Bahasa Inggris, FBS,Universitas PGRI Indraprasta Jakarta \\ *Email: muthia.mubasyira@yahoo.com
}

\begin{abstract}
Marketing strategy is very important in business processes. This process is the final process of a production. Community service activities are carried out in the rice fields of Ciputat sub-district, South Tangerang, West Java. This activity focuses on empowering orphanage students, especially in the provision of effective marketing methods, it is hoped that pondok students have an interest in entrepreneurship. The number of participants was 26 children. The activity will take place from the beginning of December 2019 until March 2020. The implementation method is used with counseling, mentoring and program evaluation. Achieved results: students can independently market products according to target sale, students know the market share, and can use online marketing.
\end{abstract}

Keywords: strategy, marketing. processed banana

\begin{abstract}
Abstrak
Strategi pemasaran sangat penting dalam proses bisnis. Proses ini merupakan proses akhir dari suatu produksi. Kegiatan Pengabdian kepada masyarkat dilakukan di Kelurahan sawah kecamatan Ciputat Tangerang Selatan Jawa Barat. Kegiatan ini berfokus kepada pemberdayaan siswa pondok anak yatim khusunya pembekalan cara pemasaran yang efektif diharapkan para siswa pondok mempunyai minat berwirausaha. Jumlah peserta sebanyak 26 anak. Kegiatan berlangsung pada awal Desember 2019 sampai dengan Maret 2020. Metode pelaksanaan yang digunakan dengan penyuluhan, pendampingan dan evaluasi program. Hasil yang dicapai : siswa dapat dengan mandiri memasarkan produk sesuai dengan target penjualan, siswa mengetahui pangsa pasar, serta dapat menggunakan pemasaran melalui daring.
\end{abstract}

Keywords: strategi, pemasaran. produk olahan pisang

\section{PENDAHULUAN}

Strategi pemasaran adalah salah satu kegiatan-kegiatan pokok yang dilakukan oleh usaha untuk mempertahankan kelangsungan usaha, untuk berkembang, dan untuk mendapatkan laba. Proses pemasaran itu dimulai jauh sejak sebelum barang-barang diproduksi, dan tidak berakhir dengan penjualan. Kegiatan pemasaran usaha harus juga memberikan kepuasan kepada konsumen jika menginginkan usahanya berjalan terus, atau konsumen mempunyai pandangan yang lebih baik terhadap usaha. Secara definisi, Strategi Pemasaran adalah penganalisaan, perencanaan, pelaksanaan, dan pengawasan program-program yang bertujuan menimbulkan pertukaran dengan pasar yang dituju dengan maksud 
untuk mencapai tujuan usaha (Kotler, 1980). Pemasaran adalah sebuah falsafah bisnis yang menyatakan bahwa pemuasan kebutuhan konsumen merupakan syarat ekonomi dan sosial bagi kelangsungan hidup usaha (Stanton, 1978). Tiga unsur konsep pemasaran: Orientasi pada Konsumen; Penyusunan kegiatan pemasaran secara integral, dan Kepuasan Konsumen. Selanjutnya ,pisang kepok merupakan salah satu produk yang dapat diolah menjadi berbagai macam produk olahan.

Produk olahan pisang kepok ,merupakan produk yang banyak diproduksi oleh kalangan remaja, orang tua dan kalangan milenial. Nama produk pisang sudah beragam, baik dari segi harga, segmen dan variasi olahan produknya. Produk pisang kepok, sudah menjamur dipelbagai tempat, baik di daerah perkotaan dan pedesaan. Hal ini perlu diantisipasi dengan penyediaan produk olahan yang baik dan terjangkau harganya ,serta semakin beraneka ragamnya selera konsumen yang menuntut adanya diversifikasi produk baik jenis maupun penyajiannya. (Mangunsong, 2001).

Penyediaan poduk yang baik, tidak dapat berdiri sendiri, kehandalan pemasaran yang baik, sangat diperlukan guna pencapaian target yang tepat dan cepat. Jika dapat dilakkan dengan tepat strategi pemasaran yang dilakukan akan membuahkan hasil ang maksimal, yaitu memasarkan produk sesuai denganproduksi olahan dan keuntungna yang diinginkan. Strategi pemasaran yang dibuat hendaknya haruslah mempertimbangkan situasi dan keadaan perusahaan baik keadaan intern perusahaan itu sendiri atau lingkungan usaha mikro, maupun keadaan ekstern perusahaan atau yang dikenal dengan lingkungan makro perusahaan. Suatu usaha yang berjaya dan mampu mempertahankan serta meningkatkan lagi penjulannya ditengah-tengah pesaingnya adalah usaha yang telah berhasil menetapkan strategi pemasarannya serta strategi bersaingnya dengan tepat.

Berdasarkan uraian diatas maka, tim pengabdian masyarakat ,ingin memberikan penyuluhan dan sosialisasi strategi pemasaran olaha pisang, kepada para pemuda/I yang ada di lingkungan kelurahan Sawah Ciputat, khususnya anak - anak yatim piatu dengan tujuan, agar para siswa pondok mempunyai kemampuan memasarkan produk olahan dengan baik dan memupuk rasa kewirausahaan.

\section{METODE PENGABDIAN}

Metode Kegiatan penyuluhan dan sosialisasi ini, dilakukan dengan menggunakan dua metode yakni penyuluhan dan pendampingan serta evaluasi program.

Sasaran utama pada pelaksanaan kegiatan pengabdian ini adalah 26 orang anak yang terpilih secara acak. Evaluasi untuk mengetahui keberhasilan dan kebermanfaatan kegiatan ini dilakukan baik pada hasil maupun proses. Hasil kegiatan pelatihan berupa penyuluhan dan strategi yang diberikan di lokasi kelurahan sawah Ciputat. Adapun hasil dari proses pelatihan dilakukan dengan pengamatan disertai dengna pendampingan proses kegiatan .

Rincian program pengabdian masyarakat yang dilakukan sebegai berikut :

a. Siswa diperkenalkan beberapa media pemasaran ,seperti brosur, pamplet dan lain - lain.

b. Siswa diberikan penyuluhan bersama para dosen dan pengurus lingkungan setempat

c. Siswa mengikuti kegiatan penyuluhan dan sosialisasi strategi pemasaran selama 2 x 60 menit, dan acara penutupan serta evaluasi teori dan praktek, 
adapun materi yang diberikan meliputi:

1. Jenis pemasaran door to door

2. Pemasaran secara online

3. Target pasar yang tepat

4. Program discount

5. Motivasi pemasaran yang handal.

Tim pengabdian masyarakat, akan mengevaluasi materi yang sudah disampaikan, baik teori dan praktek.

\section{HASIL DAN PEMBAHASAN}

Bagian Para peserta mengikuti program penyuluhan dengan baik, serius dan seksama. Para dosen memberikan tahapan pelaksanaan sesuai dengan metode pelaksanaan yang sudah direncanakan, sehingga dapat berjalan dengan baik.

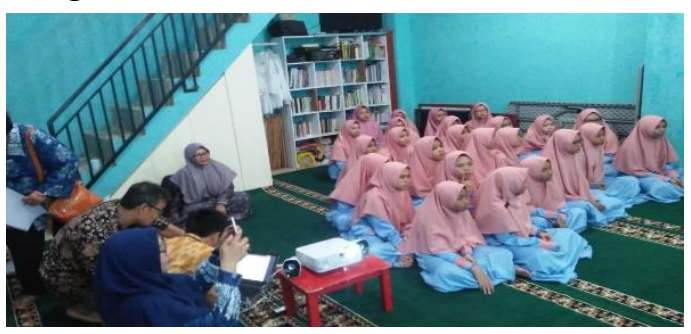

Gambar .1 .Kegiatan penyuluhan

Pada gambar 1 , para peserta tengah mengikuti sosialisasi strategi pemasaran produk olahan pisang kepok, di kampung sawah Tangerang Selatan. Adapun materi yang disampaikan meliputi, Jenis pemasaran door to door , Pemasaran secara online, target pasar yang tepat, program discount, dan motivasi pemasaran yang handal.

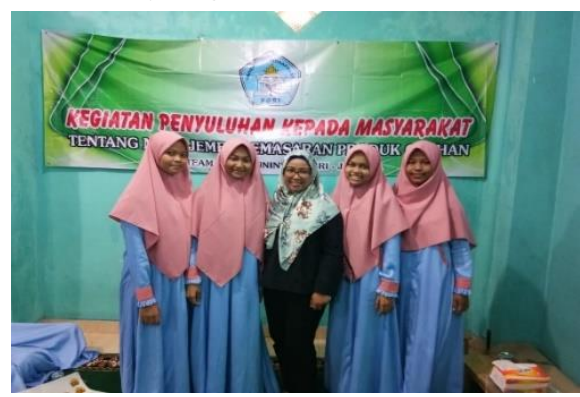

Gambar. 2. Siswi pondok yang terpilih menjadi tim terbaik
Pada gambar 2, tim pengabdian masyarakat memilih 4 dari peserta terbaik, yang dapat mengikuti kegiatan dengan baik. Mereka dapat menjabarkan beberapa teknik pemasaran yang sudah dijelaskan oleh para penyuluh, diantaranya :

a) Menggunakan Social Media.

b) Menawarkan Produk Secara Gratis.

c) Memilih Tempat Strategis.

d) Memberi Insentif untuk Rekomendasi.

e) Menjalin Hubungan Baik dengan Pelanggan

Pada kegiatan praktek mereka dibagi menjadi 5 kelompok , masing - masing memilih teknik pemasaran yang sudah diberkan seperti diatas, dan hasil yang dicapai rata -rata sudah baik. Penggunaaan sosial media ,berperan penting dalam keberhasilan pemasaran, penawaran produk gratis diwilayah mereka juga cukup penting, begitu pula dengan insentif rekomendasi dan hubungan baik kepada pelanggan.

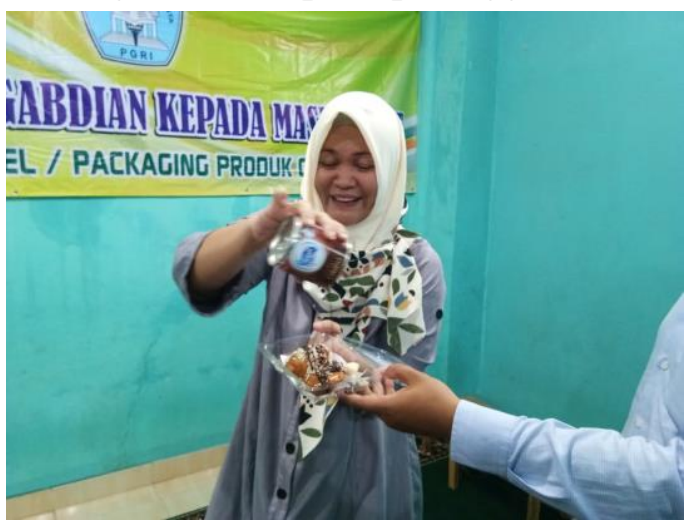

Gambar. 3. Tim memberikan contoh penyajian dan packaging produk.

Setelah tim pengabdian masyarakat memberikan penyuluhan dan penguatan strategi pemasaran, kelompok yang telah dibagi menjadi 5 kelompok, mempraktekan strategi penjualan yang telah di latih . Beberapa kelompok telah melakukan pemasaran produk di tempat 
- tempat seperti pasar, sekolah, masjid dan tempat tempat yang strategis lainya.

Setelah selama 7 hari dilakukan pemasaran berikut hasil pendapatan per kelompok dalam ribuan rupiah :

Tabel 1. Tabel Hasil Penjualan

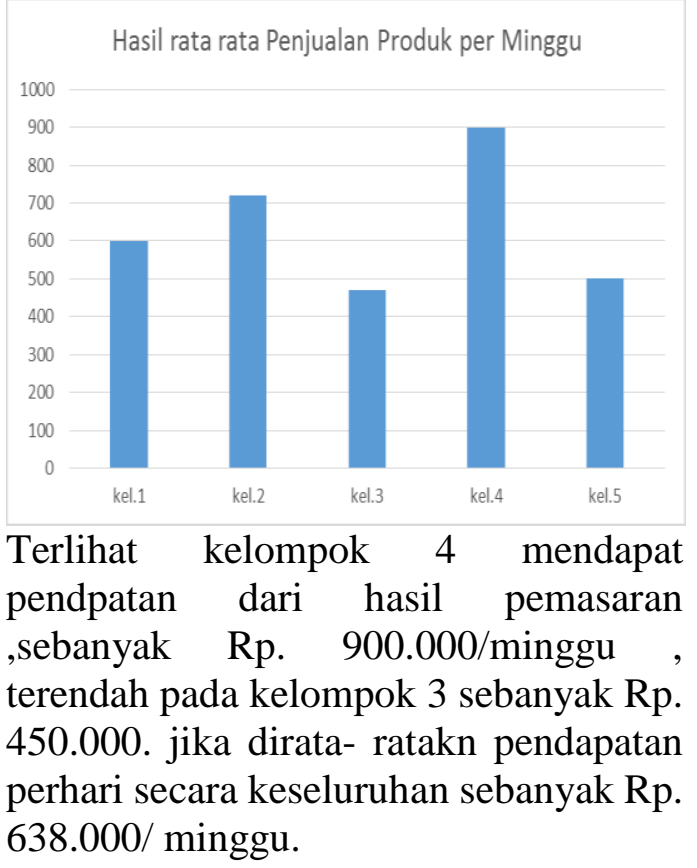

\section{SIMPULAN}

Kegiatan ini dapat memberikan wawasan peserta ,agar dapat meningkatkan penulan dan teknik pemasaran produk olahan pisang. Dengan berbekal modal yang relatif kecil, para peserta sudah berani mencoba untuk memasarkan produk tersebut . Pendampingna yang dilakukan oleh para tim dosen, dapat memberikan manfaat kepada para peserta untuk meningkatkan penjualan produk.

\section{UCAPAN TERIMA KASIH}

Ucapan terima kasih kepada seluruh pengurus Desa kampung sawah yan dapat memfsilitasi kegiatan. Ucapan terimakasih kepada para tim dosen prodi lain, yang dapat bekerjasama dengan baik, semoga dapat ditingkatkan pada kegiatan selanjutnya. Tim mengucapkan teriama kasih kepada pihak pihak yang dapat membantu baik moril maupun materi, diantaranya para pengurus yayasan dan para tim pengurus desa kampung sawah Ciputat Tangerang Jawa Barat.

\section{DAFTAR PUSTAKA}

[1] Kotler, P.(1980), Marketing Management: Analysis, Planning, and Control. 4th Ed.London: Prentice-Hall, Inc

[2] Mangunsong, Setia, MM. 2001. Kebijakan Pembinaan dan Pengawasan Mutu Hasil Perikanan. Bahan Pelatihan Sertifikat Pengolahan Ikan. Direktorat Jenderal Perikanan. Jakarta

[3] Stanton, .J.(1978),Fundamentals of Marketing, 5th Ed. Tokyo: Kogakusha, McGraw-Hill Book. Company

[4] Sunarmintyastuti, L., \& Widiyarto, S. (2019). Pelatihan Pembuatan Prakarya Dalam Rangka Meningkatkan Minat Berwirausaha Siswa. Matappa: Jurnal Pengabdian Kepada Masyarakat, 2(2), 134-137.

[5] Vernia, D. M., Widiyarto, S., Wulansari, L., \& Rusdi, M. (2018). Penyuluhan Dalam Meningkatkan Partisipasi Program Dana Desa. Prosiding Sembadha, 1(1), 72-78.

[6] Vernia, D. M., Suprapto, H. A., \& Supandi, A. (2018). Penyuluhan Pentingnya Minat Kewirausahaan Dalam Membentuk Karakter Mandiri Siswa Smk Insan Mulia dan SMP Azzuhriyah Kota Bekasi. MATAPPA: Jurnal Pengabdian Kepada Masyarakat, 1(2), 54-59.

[7] Yusuf, M. (2007). Kajian pemasaran dan pengembangan Value Added Product dengan pemanfaatan rajungan menjadi produk olahan (Doctoral dissertation, program Pascasarjana Universitas Diponegoro). 